\title{
Prophetic social sciences: toward an Islamic-based transformative social sciences
}

\author{
Pradana Boy ZTF
}

Department of Malay Studies, National University of Singapore; and Faculty of Islamic Studies, Muhammadiyah University of Malang E-mail:pradana.umm@gmail.com

\begin{abstract}
This article discusses of one of the most important type of social sciences developed in Indonesian context. In the midst of debate between Western secular social sciences and Islamic social sciences, Kuntowijoyo offered a genuine yet critical formula of social sciences. The formula called Ilmu Sosial Profetik (ISP) attempted to build a bridge between secular social science and Islamic inclination of social science. This article describes the position of ISP in the context of critical position of Muslim social scientists on the hegemony and domination of Orientalist tendency in studying Islam. At the end, the author offers a conclusion that ISP can actually be regarded as Islamic-based transformative science that can be further developed for a genuine indigenous theory of social sciences from the Third World.
\end{abstract}

Artikel ini membahas salah satu tipe paling penting dari ilmu-ilmu sosial yang dikembangkan dalam konteks Indonesia. Di tengah perdebatan antara ilmu-ilmu sosial Barat sekuler dan ilmu social Islam, Kuntowijoyo menawarkan formula yang orisinal dan kritis dalam ilmu sosial. Formula yang kemudian disebut dengan Ilmu Sosial Profetik (ISP) berusaha untuk membangun jembatan antara ilmu 
sosial sekuler dan kecenderungan untuk melakukan Islamisasi ilmu sosial. Artikel ini menjelaskan posisi ISP dalam konteks posisi kritis ilmuwan sosial Muslim pada hegemoni dan dominasi kecenderungan orientalis dalam mempelajari Islam. Pada akhirnya, penulis menawarkan kesimpulan bahwa ISP sebenarnya dapat dianggap sebagai ilmu sosial transformatif berbasis Islam yang dapat dikembangkan lebih lanjut sebagai teori sosial yang berkembang dari Dunia Ketiga.

Keywords: Social sciences; Islam; Transformative; Prophetic paradigm

\section{Introduction}

The impact of Western colonial power in Southeast Asia took several forms. One of them is manifested in the form of backwardness taking place among Southeast Asian societies in general. In relation to Muslims, Western colonialism has also created economic and political marginalization ${ }^{1}$. The emergence of Western colonial power had dramatically changed the history of Indonesia-Malay world within the constellation of international history. The settlement of Malacca by Portugal in 1511, the capture of Banten and Batavia by Dutch colonial power in 1596 and 1602 respectively brought radical impacts on economic and political establishment of Muslims in those areas. In Java, the Demak Sultanate was weakened and finally met its fate after its consecutive attempts in 1513, 1551, and 1574 at taking over Malacca from Portugal were failed. Furthermore, the domination of colonial power in economy also marginalized economic role of Muslim merchant class.

On the intellectual level, the colonial heritage can also be traced in the form of Western ideas institutionalized within the framework of Southeast Asian intelligentsia. Since Western ideas are integral parts of Western colony and are always in line with their imperialistic mission,

${ }^{1}$ A.E. Priyono, "Editor Introduction", inKuntowijoyo, Paradigma Islam: Interpretasi untuk Aksi, Bandung: Mizan, 2008, 9-16. 
the Western ideas on society were commonly applied in understanding others; and are always devoted to satisfy their interest. Therefore, if those theories and ideas are simply applied in order to gain understanding of other societies' without any modification, this will pave the way for the misleading portrayal of certain specific societies. Responding this situation, a new awareness rose among contemporary Asian experts in social sciences, and consequently they frequently refer the inappropriateness of Western social sciences in analyzing problems of Southeast Asian societies. ${ }^{2}$ It is understandable when such criticism circulated within social scientists in Southeast Asia, since knowledge cannot be separated from society. Sociologically speaking, knowledge is socially constructed. This indicates that social circumstances cannot be neglected in the forming of certain knowledge. In addition, if comprehending society means searching for human essence, the intertwining of knowledge and society becomes much more obvious, as "the search for human essence, has been an exercise in construction that cannot be divorced from social, historical, or technological conditions". ${ }^{3}$ August Comte, the founding father of modern sociology, put forward that positivism is the ultimate form of knowledge and therefore included positivistic elements within the social sciences. Many believe that in so doing, Comte himself did not intend to construct sociology as a positivistic discipline. Rather, positivism was a major narrative during his time; and based on such circumstance, his construction of sociology could not leave positivism aside. ${ }^{4}$ As a method, positivism was firstly embodied in the natural sciences and served as one of its most

2 Syed Farid Alatas, Alternative Discourses in Asian Social Science, New Delhi, Thousand Oaks, and London: SAGE Publications, 2006.

3 M. Andrew Koch, Knowledge and Social Construction, Lanham: Lexington Book, 2005, 2.

${ }^{4}$ L. Layendecker, Tata Perubahan dan Ketimpangan: Suatu Pengantar Sejarah Sosiologi, translated by Sumekto, Jakarta: Gramedia, 1983. 
important traits. In this relation, Comte believed that natural sciences has successfully been built through certain methodology and principles; and for this reason, he pronounced that the time for social sciences to apply those principles was coming. ${ }^{5}$

It has been long believed in the Western positivistic tradition that knowledge is value-free and objective. But, the claim of Western knowledge objectiveness is subject to doubt of non-Western social scientists, including Muslim theorists. Even in the Western society, the skepticism over the objectivity of science has also long-existed. Structuralism and functionalism, for example, contained bias of bourgeois society seeking for dynamic equilibrium. ${ }^{6}$ Similarly, Ismail Raji' al-Faruqi, one of the leading critics of Western social sciences, pointed out that such an objectivity is a "vain claim". He stated:

Western social scientists impudently declare their investigation objective. But, we know that they are biassed and that their conclusions are of limited significance... theory after theory was erected to force the data into a mould, the categories of which were part and parcel of the Western world-view. ${ }^{7}$

Furthermore, it can also be seen that Western social scientists study other religions as part of scientific objective. In this relation, Faruqi argued:

The Western mind was still a long way from realizing that understanding the religions, civilizations and cultures of other peoples requires an opposite bias, empathy with the data, if the data were to be understood at all. ${ }^{8}$

${ }^{5}$ Ismail Raji al-Faruqi, "Islamizing the Social Sciences", in Ismail R. al-Faruqi and Abdullah Omar Naseef (eds.), Social and Natural Sciences: The Islamic Perspective, Jeddah: King Abdullah University, 1981, 9-10.

${ }^{6}$ Kuntowijoyo, Muslim Tanpa Masjid, Bandung: Mizan, 2001, 102.

7 Ismail Raji' al-Faruqi, "Islamizing the Social Sciences", 12-13.

${ }^{8}$ Ismail Raji' al-Faruqi, "Islamizing the Social Sciences", 13. 
Such a diagnosis by al-Faruqi on the nature of Western social sciences developed in certain circles of Muslim intelligentsia. However, the responses of the Third World's, including Muslim, intelligentsia to this situation vary from one to another. On the one hand, the inappropriateness of Western social sciences for Asian context, especially in the Muslim world, is implemented in the form of Islamization of several, if not all, branches of knowledge. The idea of Islamization of knowledge introduced by Syed Naquib Alattas and Ismail Raji' al-Faruqi can be classified as one form of alternative discourse. Other response to Eurocentrism and Orientalism was to do with methodology and the nature of Orientalists' works. Among the earliest critique of Orientalism from Muslim tradition are Maryam Jameelah, A.L. Tibawi, Anouar Abdul Malek and Syed Husin Alatas. ${ }^{9}$ Later, criticism was also developed by Edward Said through his polemical critique of Orientalism. Among those critics, Edward Said's severe and polemical criticism to Orientalism has attracted wider attention; and since then Said's Orientalism is referred as a major critical voice to the Eurocentrism. Beside those afore-mentioned responses, other types of critiques were also developed by Frantz Fanon, Gayatri C Spivak, Homi Bhaba and Bill Aschroft, who cultivate their criticism to the Orientalism based on their own context, experience and circumstances.

Joining this wave of critical attitude toward Orientalism, critique toward Orientalism can also be understood from an Indonesian setting. Amien Rais' statement can be proposed as evidence. Although Rais did not systematize his critique as those afore-mentioned thinkers, his critical attitude to Orientalism is important to note. As a graduate from an American university, during his stay for study in the US, Rais main-

9 Ziauddin Sardar, Orientalism, Buckingham: Open University Press, 1999. 
tained good relationship with prominent Orientalist Leonard Binder. It is probably as a result of his encounter with Binder that Rais then criticized the Orientalist tendency in describing other societies and religion, especially Muslim communities. About Binder, he stated: "... he is regarded as one of the most prominent Orientalists. He has written many books and all, with no exception, insulting Islam... recently he has lost his intellectual credibility after many scholars found his racial and ethnocentric approach in producing knowledge". ${ }^{10}$ Unavoidably, the twin effect of Western colonialism on Asian countries or Muslim world in general namely the backwardness and intellectual hegemony, has also attracted response from some Arab thinkers such as Hassan Hanafi. In attempt at minimizing and delineating Orientalist devastating influence on Muslim world, Hanafi proposed his theory of 'ilm al-istighrab (Occidentalism), which urge the inter-civilizational dialogue rather than letting the West define themselves as the subject and the East or the rest of the world as. ${ }^{11}$

Unfortunately, among those criticism wave to Orientalism and endeavors to construct alternatives discourses for indigenous-based social sciences, not too many voices can be heard from Indonesia, except some sporadic critical statements as Amien Rais' quoted above. Given the fact that Indonesia is a fertile land for Islamic thought and social sciences, Orientalists' legacy shows its prominence. Asaf Hussain describes that among Orientalists' victory in the Third World is that they have successfully equipped their non-Western students with set of paradigms that suit their interest. Consequently, those paradigmatic set is merely implemented in those students' own countries when they

\footnotetext{
10 See Ulumul Qur'an, Volumer 3, Number 5, 1994.

${ }^{11}$ See Hassan Hanafi, Oksidentalisme: Sikap Kita terhadap Tradisi Barat, Jakarta: Paramadina, 1999.
} 
come back, without any awareness of the uniqueness of knowledge they inherit from their Orientalist masters and willing to reconstruct and modify those legacies. ${ }^{12}$ It is not difficult to find such as a situation in the Indonesian context, where scholars having education from West merely transfer their understanding of society based on their masters' methodology without any awareness of its distinctiveness where the knowledge was based and emerged on the one hand, and the limitation and subjectivity of certain paradigms on the other. More than three decades ago, Syed Husin Alatas (1977) has rightly described those who are trapped in this situation as scholars with "captive mind." The "captive mind" scholars show such traits as: blind imitation of the West, uncritical to Western sources or any other sources coming from outside, and that they are not conscious that they are captured by certain ideologies and ways of thinking. ${ }^{13}$ Interestingly, three decades after S.H. Alatas criticism, the "captive mind" tendency, especially in Indonesian intellectual environment, is still well-developed and maintained very smoothly.

It is not surprising, therefore, that in Indonesia, scholars critical to the Western scientific tradition is rarely found. As a result, social theories developed by Western social scientists are employed to understand Indonesian society without any critical consideration of the appropriateness with the uniqueness of society. Just to take a very popular example we can refer to Clifford Geertz's classical theory of Religion of Java that classified Javanese Muslims into three categories of abangan, priyayi and santri Muslims. While this theory was unable to fully understand the real situation of complicated Javanese blend of culture, society, and social class and has been criticized by some Indo-

\footnotetext{
${ }^{12}$ Asaf Hussain, Orientalism, Islam and Islamists, Vermont: Amana Book, 1984.

${ }^{13}$ S. H. Alatas, The Myth of the Lazy Native, London: Frank Cass, 1977.
} 
nesian social scientists, it still shows its efficacy within certain circles of social scientists in Indonesia. Among those rare critical and alternative voice was Koentjaraningrat and Kuntowijoyo. Specifically refer to the later, Kuntowijoyo was a leading historian and social scientist who was involved in ongoing attempts to construct a new paradigm of Islamic social sciences. In doing so, he utilized the Qur'an as the paradigm of his social theory, considering the uniqueness of Indonesian Muslim society's features and cases, but interestingly at the same time he also critically employed Western ideas to support his theory. This can be seen as a model of how Muslim social scientists should show their attitude toward Western scientific heritage. Kuntowijoyo has shown that being critical to the West and committed to Islamic knowledge is not always equal whole negligence of Western theoretical legacy and contribution. Given the importance of Kuntowijoyo's contribution to the development of social sciences in Indonesia, this paper will deal with one of indigenous social theories developed by Kuntowijoyo that is widely known as Ilmu Sosial Profetik (Prophetic Social Sciences, hereafter I will refer to as ISP) or later also known as Sosiologi Profetik (Prophetic Sociology). In next sections, the paper will discuss the origin of the theory, basic traits of the theory and its position within the context of alternative discourses in social sciences in Asia as well as Islamic thought in Indonesia. This essay will be ended with critical note and conclusion.

\section{Biographical sketch}

Kuntowijoyo was born in a small village of Yogyakarta on 18 September 1943 . Widely known as a prominent historian, he served as lecture and later professor of history in the University of Gadjah Mada (UGM), Yogyakarta, Indonesia. This position was held until his death on 22 
February 2005, in Yogyakarta. His death was a big loss for Indonesian intellectualism of social sciences as well as literature. Because, although he was academically an historian, Kuntowijoyo is a name with various attributes. He is a well-known novelist, poet, preacher at the mosque as well as an activist. The wide range of his works is evidence of this claim. His works on history includes: Dinamika Sejarah Umat Islam Indonesia (1985), Budaya dan Masyarakat (1987), Radikalisasi Petani (1993), Metodologi Sejarah (1994, Pengantar Ilmu Sejarah (1995), Raja, Priyayi dan Kawula: Yogyakarta 1990-1915 (2004) and Peran Borjuasi dalam Transformasi Eropa (2005). Among his literary works are: Kereta Api yang Berangkat Pagi Hari (novel, 1966), Rumput-Rumput Danau Bento (1968), Pasar (1972, reprinted in 1994), Khutbah di Atas Bukit (1976), Mengusir Matahari (1999) and Mantra Pejinak Ular (2000).

Kuntowijoyo also deserved adoration for his attention to Islamic thought that is also particularly high. In addition to those works on history and literary works, he also built his own understanding of Islamic thought through his books, Paradigma Islam: Interpretasi untuk Aksi (first published in 1991 and reprinted in new edition in 2008), Identitas Politik Umat Islam (1997), Muslim Tanpa Masjid (2002), Selamat Tinggal Mitos, Selamat Datang Realitas (2002), and Islam sebagai Ilmu: Epistemologi, Metodologi dan Etika (2004).

His initial education was finished in Yogyakarta. In 1969 he completed his undergraduate studies in history from the Gadjah Mada University in Yogyakarta. After finishing his undergraduate, he left for the United State to pursue his master degree in history at the University of Connecticut in 1974. Six years later, he obtained his Ph.D in history from Columbia University. Upon the completion of his study, Kuntowijoyo returned to Indonesia and assumed lectureship position in his almamater and later professor of history in the same university. 
Kuntowijoyo also spent some time teaching abroad, namely in the University of Philippine (1984) and the University of Michigan (1985). He was also an activist of Muhammadiyah and key figure in some study circles in Yogyakarta.

\section{Prophetic social sciences}

Given his significant contribution to the development of alternative discourses in social sciences in Indonesia and may be in Southeast Asia, studies on Kuntowijoyo's thought is considerably limited. His theories are widely cited and debated by intellectuals, students and researchers working on Indonesian thought whether in the field of Islamic thought, history, social sciences and literature. This is a clear evidence of how influential his theory was and still is. He was an outstanding historian that did not confine himself in the discipline of history but also appropriately and critically utilized social sciences for the purpose of social transformation. Although he is also critical to some Western social thought, he utilized some of those theories to describe Islam in Indonesia. As Woodward identifies that some Indonesian Muslim intellectuals, especially who are trained in social sciences and humanities, "employ methods similar to those of their Western counterparts, but they are also concerned with question of religious thought."14 This assertion can be used to describe Kuntowijoyo's case very well. He critically employed theories such Thomas Kuhn's "paradigm", Levi's Strauss' "structuralism," Peter L Berger's "objectification" or Antonio Gramsci's "relative autonomy" and applied those theories in attempts to comprehend the nature of Muslim societies.

\footnotetext{
${ }^{14}$ Mark R. Woodward, "Talking Across Paradigm: Indonesia, Islam and Orientalism", in Mark R. Woodward (ed.), Toward A New Paradigm: Recent Developments in Indonesian Islamic Thought, Arizona: Arizona State University Press, 1996, 6.
} 
As a result of his long intellectual journey, he has successfully initiated his most popular theory called "Ilmu Sosial Profetik (ISP)." This theory was motivated by awareness that contemporary social sciences are stagnant. They are successful in describing society and its phenomena, but they failed to transform society. In its relation to Muslim societies, Kuntowijoyo argued that the key answer behind the backwardness of Muslim world is the lack of connectivity between theories and practices, or between knowledge and facts. Furthermore, Kuntowijoyo also acknowledged that the domination of Western paradigm in Muslim social sciences has significantly contributed to create the distance between theories and realities. He argued:

The social sciences we are developing only make people isolated from their society or make them alien to Islam. This is because we have been developing transplanted knowledge, not rooted in (our) society. Those sciences also adopt clear-cut dichotomy of facts and values, having positivistic bias as natural sciences do, as if social sciences are value-free, objective and purely empirical. We are embarrassed to acknowledge the interconnectedness of social sciences with socio-cultural values, we are scared to be blamed for being not scientific and objective. ${ }^{15}$

In order to prove his description of the lack of interrelation between knowledge and facts in the Indonesian Islam context, Kuntowijoyo then described three traditions of knowledge that developed in the country. According to his observation, by understanding these types of knowledge, a paradigmatic reform can be initiated. Those three types of knowledge are: normative, ideological, and scientific. The normative knowledge manifested in two types of "declarative" and "apologetic" knowledge. Declarative knowledge of Islam, Kuntowijoyo argued, is

${ }^{15}$ Kuntowijoyo, Ilmu Sosial Profetik sebagai Gerakan Intelektual, Selangor: Akademi Kajian Ketamadunan, 2004, 1. 
important for missionary nature of Islam. Therefore, this kind of knowledge is common within the circles of pesantrens and religious schools. Usually, this knowledge is also developed by publishers with strong $d a$ wah orientation. The apologetic type of knowledge, on the other hand, emerged as the result of Orientalist and Western hegemony and approach to Islam. Since they tend to discredit Islam whether in field of sciences, mass media as well as politics, ${ }^{16}$ apologetic knowledge emerged as a rejoinder to show that Islam is not as they understood and portrayed. But, the way they responded to the Western stereotypical understanding of Islam is far from academic and scientific formulation, so the apologetic type of knowledge has made Western negative views on Islam much even greater.

Similarly to the first type, the ideological knowledge aimed at bringing Islam as the major ideology of Islamic movements. Some important aspects, however, were ignored by this type of knowledge namely social theory, analysis, strategy and method. Ideological knowledge discuss the greatness of Islam, but it never come up with analytical encounter on why Islamic civilization then later declined. As stated before, Kuntowijoyo critically employed Western without any failure to criticize them. This is the case with his description of the third type of knowledge. On scientific knowledge, Kuntowijoyo objectively praised and appreciated the contribution of Western social scientists such as Snouck Hurgronje, Schrieke, Pijper and Clifford Geertz. It is true that they were not free of interest, but "their empirical methods are praiseworthy". ${ }^{17}$

Within such an intellectual situation, Kuntowijoyo pointed out, those three traditions of knowledge, Islamic knowledge have been trapped in

\footnotetext{
${ }^{16}$ Kuntowijoyo, Muslim Tanpa Masjid, Bandung: Mizan, 2001, 106.

${ }^{17}$ Kuntowijoyo, Muslim Tanpa Masjid, 103-105.
} 
sintagmatisme, namely the abundant attention paid on the syntax of the theory. Using Thomas Kuhn's paradigm, Kuntowijoyo labeled those types of knowledge has become "normal science". Kuhnian paradigm states that when a science is becoming "normal" that means it will tend to maintain the establishment, never think of any possibilities for creating breakthrough and new paradigms. While, on the other hand new paradigms of sciences can only be obtained through changing the commitments. Kuntowijoyo described what kind of commitment that should be changed.

The commitment of normative knowledge is da'wah, the ideological tradition committed to politics, while scientific tradition's commitment is science. The new paradigm should posses new commitment as well, namely ummah (society, communities, peoples, tribes, nation). We will call this new paradigm as IImu Sosial Profetik. ${ }^{18}$

This describes the background of ISP that showed Kuntowijoyo's commitment to constructing social theories that at the same time rooted in Islamic tradition, without being "declarative" and "apologetic" and locating social transformation within the very core of his theory building. His creation is meant to show the scientific dimension of Islam, but he tried to construct that scientific element not in the sense of Western Orientalists understood the terms, since their paradigms and methods are sometimes biased.

From this point a clear indication can be underlined namely the interrelation of knowledge production and social and even political context. Social context is defined not only as social empirical situation, but it is broadened to the intellectual atmosphere developed within society. In this light, many Indonesian intellectuals believe, such as Dawam Rahardjo (2008), that Kuntowijoyo's theory of ISP is a result of his

\footnotetext{
${ }^{18}$ Kuntowijoyo, Muslim Tanpa Masjid, 106.
} 
interaction with and critique to Moeslim Abdurahman's theory of "liberation theology" that constitutes the core of Abdurrahman's ideas of "transformative theology". It is almost impossible to deny Rahardjo's assertion since Kuntowijoyo himself acknowledged his interaction with Moeslim Abdurrahman's ideas and from that point he later developed the ISP. ${ }^{19}$ As a background information, in the late 1980s, Moeslim Abdurrahman proposed his ideas of "transformative theology" (teologi transformatif) that is later known as "transformative Islam" (Islam transformatif).

By transformative Islam, Abdurrahman intended to develop Islamic teachings as the spirit and basis for social transformation. This idea emerged as a critical reflection to the process of modernization or what is called by the New Order regime under Suharto as "pembangunan". According to Abdurrahman, rather than benefiting people in general, modernization has brought benefits only for middle upper class society. Not only created inequalities in society, at the same time it also caused the wide-spread of social marginalization, especially among peasants and labors. Consequently, although they are nominally Muslims, practicing Islamic teachings and believe in Islam as a religion and ideology; Islamic teachings have been very long time become foreign to their life, as if Islam has nothing to do with the life of those marginalized people. On the other hand, those who are involved in non-governmental organizations or civil society units do not reorient their movements toward cultural reform or even social reform to deal with the process of marginalization. Therefore, a critical and liberal theological reflection is needed to change this situation. ${ }^{20}$

${ }^{19}$ Dawam Rahardjo, "IImu Sejarah Profetik dan Analisis Transformasi Masyarakat", Foreword in Kuntowijoyo, Paradigma Islam: Interpretasi untuk Aksi, new edition, Bandung: Mizan, 2008.

20 Moeslim Abdurrahman, Islam sebagai Kritik Sosial, Jakarta: Penerbit Erlangga, 2003, 83. 
While Kuntowijoyo agreed to certain level with basic ideas of Abdurrahman's brainchild, he showed a considerably significant disagreement with Abdurrahman. Moeslim Abdurrahman's idea lies in the use of the term "theology". In Kuntowijoyo's view, referring to the Indonesian case, theology can be broadly understood in two ways. On the one hand, theology is traditionally perceived as a discipline of science that study God and His attributes. In this understanding, theology is normative, abstract and scholastic. On the other hand, theology is also comprehended in a more modern and sophisticated method which equals the "interpretation of realities in the divine perception." Theology in this sense is much more empirical reflections rather normative and doctrinal. ${ }^{21}$ In other words, Kuntowijoyo argued that Muslims do not have any problem with their theological belief, especially in its relation to the poor. However, Abdurrahman believes that when we take the relation of state power and the hegemony of development into serious consideration, we need a symbolic language that can serve as theological reflection rather than merely promoting critical social sciences. ${ }^{22}$

In this case, Kuntowijoyo classified Abdurrahman's idea in the second meaning of theology; and it is very clear that Abdurrahman's ideas of "transformative theology" contains severe criticism to traditional theology that is perceived as no longer appropriate and have to be modified. This has created ongoing debates among "traditional" and "modern" theologians" which was not easy to reconcile. Therefore, Kuntowijoyo suggested that it would be more appropriate if the spirit of Moeslim Abdurrahman's "transformative theology" was translated into

${ }^{21}$ Kuntowijoyo, Paradigma Islam: Interpretasi untuk Aksi, Bandung: Mizan, 2008, new edition, 478.

22 Moeslim Abdurrahman, Islam Transformatif, Jakarta: Pustaka Firdaus, 1995. See also Moeslim Abdurrahman, Islam sebagai Kritik Sosial, Jakarta: Penerbit Erlangga, 2003, 185. 
another nomenclature such as "transformative social sciences", although for his own theory Kuntowijoyo proposed another label namely I/mu Sosial Profetik. ${ }^{23}$

Furthermore, Kuntowijoyo formulated that his theory of ISP was constructed on the Quranic basis, especially Surah Ali Imran verse 110. This verse contains three basic teachings of amar ma'rüf (invitation to do the good things), nahy munkar (preventing people from doing blamable doings) and tu'minuna bi-Allah (believe in Allah). By quoting this verse and extracting those three basic concepts, Kuntowijoyo wanted to show that Islam is actually compatible with the development of social sciences and other discourses emerged from the context of modernity. He identifies that the amar ma'rüf as a concept has compatibility with the Western idea of progress, democracy, human rights, liberalism, freedom, and selfishness. In contrast, nahy munkar is an idea that is companionable to the liberation principles of socialism (Marxism, communism, dependency theory and liberation theology). Beyond all this, Kuntowijoyo drew an analogy of the last concept, tu'minūna bi-Allāh, with transcendence that is believed as the basic and perennial element of all religions in the world. ${ }^{24}$

In addition, Kuntowijoyo described that the intellectual origin of his theory was also derived from a Pakistani Islamic thinker Muhammad Iqbal. In one of his book, Iqbal outlined a clear distinction of the prophetic and mystical awareness. According to Iqbal, mystical awareness will only concern with the fulfillment of a sufi's spiritual quest and has less interest in social transformation. Iqbal quoted a sufi Abdul Quddus saying that Prophet Muhammad has reached the highest place, met

${ }^{23}$ Kuntowijoyo, Paradigma Islam: Interpretasi untuk Aksi, new edition, Bandung: Mizan, $2008,480$.

${ }^{24}$ Kuntowijoyo, Muslim Tanpa Masjid, Bandung: Mizan, 2001, 106. 
the God during his Isra' Mi'raj; and then he coming back again to the earth to serve the ummah. Abdul Quddus said: "In the name of Allah, if I could reach that highest place as Muhammad did, I will not come back again..." But, Muhammad did not choose to do what Abdul Quddus imagined, since Muhammad is a prophet. He came back to the ummah and embarked great social transformation through the missionary of Islamic teachings. Kuntowijoyo identified this point as the basis of his Prophetic Social Sciences. He asserted that intellectuals are the heirs of the prophet. A Muslim intellectual have to take active part in saving the world, saving the ummah. In other words, Prophetic Social Sciences is a new paradigm in social sciences based on Islamic values and aimed at social transformation within the prophetic framework of values and principles. According to Kuntowijoyo, one of the biggest interest of Islam as a social ideology is how to transform society in accordance with its idea and vision of social transformation. ${ }^{25}$

Derived from all of those explanations, Kuntowijoyo explained the three pillars on which ISP was developed. He translated the amar ma'rūf into "humanization" (humanisasi) which serves as the first pillar of ISP, nahy munkar is described as "liberation" (liberasi) and tu'minūna bi-Allāh as "transcendence" (transendensi) which constitute the second and third pillars of ISP respectively. Modernity, in Kuntowijoyo's view, has caused the process of dehumanization through the medium of technology, market and state. Technological society is a society determined by economic resource. Therefore, economy will determine social stratification, system of knowledge and environment ${ }^{26}$. This situation will lead to pragmatic and materialistic points of view that perceive and appreciate human beings not from their humanity, but rather from

\footnotetext{
${ }^{25}$ Kuntowijoyo, Paradigma Islam, 564.

${ }^{26}$ Kuntowijoyo, Muslim Tanpa Masjid, 2001, 367-368.
} 
their economic wealth. Kuntowijoyo concluded that in industrial age, human beings are vulnerable of falling, losing their humanity. Therefore, an attempt at regaining their humanity is an urgent need. ${ }^{27}$

The mission of humanizing the human then has to be accompanied by liberation processes which will liberate human being from hegemony of the text, system of knowledge, social system, economic system and political system. Although Kuntowijoyo did not explicitly assert the liberation from the text, it is clear that he pointed textual hegemony as one of the basic obstacle for the transformation of Muslims' way of thinking that will finally correlate to the social transformation. The text in this context refer to the Quran and by liberating Muslims from the hegemony of the text does not mean leaving Quran aside from the formulation of transformative social theory. Rather, liberation in this sense relate to the demystification of certain interpretation of the Quran. The Quran, in Kuntowijoyo views, is a paradigm for the formulation of social sciences. According to analytical approach in understanding Quran, Quranic verses are basically normative statements that need to be analyzed in objective level. It means that the Quran should be formulated in theoretical construction that will constitute the Quranic theory building. From this point, the Quran as a paradigm will emerge. ${ }^{28}$

Liberation of system of knowledge relates with endeavors to liberate people from materialistic system of knowledge and structural domination. At the same time, a social change is also taking place. Indonesian Muslims experiencing a transition from agrarian society to industrial social system. At the same time with industrial age penetration, capitalistic economic paradigm is also taking place and made further alienation and marginalization of human beings. So, the freedom from manacling

\footnotetext{
27 Kuntowijoyo, Muslim Tanpa Masjid, 369.

${ }^{28}$ Kuntowijoyo, Paradigma Islam, 553-554.
} 
economic system should become shared major attention. Such a principle is also evident from some Qur'anic verses. The last element of liberation is political liberation. Kuntowijoyo viewed the compatibility of ideas of democracy, human rights, and civil society with Islamic teachings and values. Therefore, political liberation means liberating the system from authoritarianism, dictatorship and neo-feudalism. ${ }^{29}$

Regarding the third pillar of ISP, transendensi, Kuntowijoyo valued transcendence as "the awareness of the Godness". It does not necessarily mean the awareness of the Godness in religious sense, but it can be all kinds of awareness that go beyond humanity borders. However, Kuntowijoyo still believed that it is on the hand of religious peoples that an idea of transcendence will be effective for humanity, as transcendence will mean faithful in the God, the Most Merciful ${ }^{30}$. In Islamic tradition, the transcendence (transendensi) is in the form of Sufism. The Sufism teaching such as khauf(fear), rajā'(expectation), tawakkal (submit all to Allah), Qanā'ah, shukur, ikhlāṣ are topic of transcendental literary." ${ }^{131}$ All his literary works are devoted to the idea of transendensi. Therefore, ISP as an alternative discourse for materialistic, secular and positivistic social science has to distinguish itself by paying attention to the unworldly dimension of the life; and transcendence is meant to achieve that objective.

As Peter L Berger and Thomas Luckman noted that "reality is socially constructed and that the sociology of knowledge must analyze the process in which this occurs," ${ }^{\prime \prime 2}$ Kuntowijoyo always emphasized the importance of bringing normative formulations to scientific, objec-

\footnotetext{
${ }^{29}$ Kuntowijoyo, Muslim Tanpa Masjid, 371.

${ }^{30}$ Kuntowijoyo, Maklumat Sastra Profetik, Yogyakarta: Grafindo Litera Media, 2006, 22.

${ }^{31}$ Kuntowijoyo, Maklumat Sastra Profetik, Yogyakarta: Grafindo Litera Media, 2006, 21-22.

32 Peter L Berger and Thomas Luckman, The Social Construction of Reality: A Treatise in the Sociology of Knowledge, New York: Doubleday and Company Inc, 1966.
} 
tive and empirical ones. The reorientation of awareness from normative to scientific level is an intellectual requirement to embark on an attempt to reformulate an Islamic social theory on social transformation. He acknowledged that nowadays there is an urgent need for a theoretical perspective on Islamic social transformation. This is because without such a theory not only that we will not be able to comprehend social realities from an Islamic perspective, but also will make us uncertain in the wave of social changes without any ability to formulate endeavors to address them. It becomes clear that we need an Islamic social theory formulation in order for us to be able to implement and actualize our faith on objective realities...33 Kuntowijoyo warned: "one thing that is absolutely needed in our attempt to formulating Islamic social theory is that in addition to referring to normative concepts of Islam, we have also to take into account objective and empirical realities within society. Obviously, Islamic social theory has its basic rudiment in the normative concepts of the Quran and Sunna, but then it has to be able to explain the actual and historical phenomena of those social realities under consideration. It is impossible for us to construct a social theory without paying attention to those objective and empirical phenomena. ${ }^{34}$ ISP marked Kuntowijoyo's unstoppable endeavors to build alternative discourse that bring together three big tasks in one single formulation, namely the building of transformative social theory based on Islamic principles, critical assessment of the Western theoretical legacy without any feeling of antipathy toward credible and reasonable Western social theories, and grounding the theory on real problem of ummah, especially taking side to the marginalized groups.

${ }^{33}$ Kuntowijoyo, Paradigma Islam, 577.

${ }^{34}$ Kuntowijoyo, Paradigma Islam, 578. 


\section{Discussion}

From the discussion on Kuntowijoyo's ideas on Ilmu Sosial Profetik, I am confident in asserting that the ISP can absolutely be categorized in the context of alternative discourses in Southeast Asian social sciences. S. F. Alatas describes the features of alternative discourses, among others, are: 1) embarking from the criticism of Orientalism and Eurocentrism; 2) problematizing methodological and epistemological aspects of the study pertaining to society, historiography or the philosophy of history; 3) commitment to elevate genuine problems in social and historical studies; 4) recognition that ideas for the social sciences gained their inspiration from all civilizations and cultural practices; and 5) they do not blindly reject the entire Western social science. ${ }^{35}$

Using Alatas' theory as a parameter, ISP is clearly part of alternative discourses. Although Kuntiwojoyo was very critical to Western social sciences methods, tradition and theories, on the one side, and on serious attempt to bring Islamic values and formulation for the creation of that alternative, on the other; Kuntowijoyo was not trapped in the form indigenization in the sense that all ideas coming from the West or from the outside should be rejected. At this point, a clear distinction between Kuntowijoyo's ISP and al-Faruqi's and Naquib Alattas' Islamization of knowledge can be clearly seen. Kuntowijoyo rejects the idea or precisely the term of "Islamisasi I/mu" as an Indonesian translation of Islamization of Knowledge. Rather, he proposed his own version of "Pengilmuan Islam", or the "Scientification of Islam". The Islamization of knowledge endeavors to bring Muslim critical of "outside" methods by referring all kinds of knowledge to the principle of Tauhid. At this

${ }^{35}$ Syed Farid Alatas, Alternative Discourse in Asian Social Sciences, New Delhi and London: Thousand Oaks and SAGE Publications, 2006, 82. 
point, parallelism of ISP and Islamization of Knowledge can be drawn, in which Kuntowijoyo also argued on the importance of transcendental element in the forming knowledge and theories. However, Kuntowijoyo viewed the Islamization cannot mean the wholesale Islamization, since there certain methods that are really objective. Unlike al-Faruqi who believed that no method is objective, Kuntowijoyo believed on the objectivity of certain theories. He stated that for those really objective methods, the Islamization is not needed. Kuntowijoyo said that we have to be selective in determining which methods are to be Islamized and which are not. Since for him, wherever the methods are the same: method of survey, participant or grounded, all can be safely used without taking any risk of contradicting to iman. "So, Islamization is partly needed and partly not."

We cannot also deny that the employment of Western method of social sciences is inevitable. However, social scientists in the developing world have to pay attention to three steps in order to contextualize those theories into local context. Firstly, formulating and internalizing religious values in order to reveal the worldview, ideas and motivation of agents of social changes in the developing world. Secondly, considering historical and factual aspects experienced by developing world's societies in order to understand why those agents of social change behave in certain ways. Thirdly, identifying the structure of traditional institutions that contain and reflect values of local societies. ${ }^{36}$ In Rahardjo's view, if these three steps are to take very rigorously, the indigenization (pribumisasi) of social sciences can be achieved. But, Rahardjo also warned that this will only be achieved if the accumulation of knowledge and the formation of social theories derived from social realities and history of society's progress taking place.

\footnotetext{
${ }^{36}$ Dawam Rahardjo, "Preface" in Kuntowijoyo, Paradigma Islam.
} 
It is also interesting to read Kuntowijoyo's pro-marginalized groups interpretation of Islam and social sciences that to some extent similar to Marxian paradigm in understanding society. However, A.E. Priyono argues that it would be a misinterpretation to draw a conclusion that Kuntowijoyo wholly adopted class perspective as understood by Marxism. In addition to his bold rejection the materialistic and secular elements in the orthodox Marxian view, he also denied a dichotomy that place religions or ideologies as such as merely reflection of structure basis, namely economy. ${ }^{37}$

Given the nature of his critical attitude toward Western theories and his deep reading of Islamic values, Shofan identifies Kuntowijoyo is influenced by Fazlur Rahman's approach to Islam and Western scientific tradition. According to Rahman, in response to modernity, Muslim scholars can be categorized into two types. The first type are those who tend to indigenize and Islamize Western theories, by referring any kinds of theories and methods emerging from the West to the Quranic principles, or to be precise Quranic verses. Other type of Muslim scholars tends to totally reject the modernity and at the same time they offer apologetic alternatives based on partial understanding of the Quran. This situation has led Rahman to create his own method that later known as "double movement" theory. The basic trait of this theory is apprehending the moral value of the Quran and then applied those basic and universal values within the context of modernity. This can be done within two steps: First is to understand the meaning of a statement by revealing the historical context and situation in which certain Quranic verses were revealed as response. Furthermore, Rahman suggested that before going on to studying the revelation of the Quran

37 Kuntowijoyo, Paradigma Islam, 69-70. 
specific context, an examination of macro situation of social context where the Qur'an was revealed has to be proceeded. Secondly, to generalize those specific responses and extracting the socio-moral value and the ratio legis of those specific answers. ${ }^{38}$

By ISP or prophetic sociology, we are demanded to develop scientific framework to continue the missions of the prophets. However, outside its advantages and disadvantages, its strength and weakness, this theory has to be regarded as one of many models of alternative discourse. It is the end and is always in a never ending process in search of better understanding of society. As Kuntowijoyo often sated that it is only with academic courage that we will be able to move forward. One thing that has to be noted is that Muslim should adopt "active awareness of history" to transform society into a more humane and just society, embarking from three elements of awareness which are humanisasi, liberasi, and transedensi. The hardest academic task in this relation is developing scientific and critical thinking ability in order to understand realities that should be related to religious and prophetic values. This is another important agenda within the light of the theory.

As a matter of intellectual discourse, Kuntowijoyo's contribution is very significant for the construction of alternative social sciences in Indonesia. However, since his theory heavily relies on intellectual reflection, while at the same time he showed his sympathy to marginalized groups, it seem slightly contradictory that at the same time he urged for social transformation, but he never been engaged in practical activism to concretize that transformation. Many argue that intellectual realm and empirical level are two different things, so that relating

\footnotetext{
${ }^{38}$ Fazlur Rahman, Islam dan Modernitas tentang Transformasi Intelektual, Bandung: Pustaka, 1995, 7.
} 
Kuntowijoyo's theory of transformation with his absence from empirical social engagement would be inappropriate. However, such an assertion is relatively weak, since there is interplay between realities and intellectual reflection. Therefore, after decades of his theoretical construction which is, once again, very significant as alternative discourse, we have to critically think of to what extent has Kuntowijoyo's influence social transformation in Indonesia. Such an assessment is important in determining whether there has been empirical connection or not. Furthermore, this also significant for the identification of future and further modifications of this theory, not by Kuntowijoyo, but by other social scientists in Indonesia or Southeast Asia in general, with their respective context.

\section{Bibliography}

Abdurrahman, Moeslim. Islam sebagai Kritik Sosial. Jakarta: Erlangga: 2003.

Abdurrahman, Moeslim. Islam Transformatif. Jakarta: Pustaka Firdaus, 1995.

Alatas, Syed Farid. Alternative Discourses in Asian Social Science. New Delhi, Thousand Oaks, and London: SAGE Publications, 2006.

Alatas, Syed Farid, "Pengkajian Ilmu-Ilmu Sosial: Menuju ke Pembentukan Konsep Tepat", Antropologi Indonesia, Number 72 (2003): 1-23.

Alatas, Syed Husin. The Myth of the Lazy Native: A Study of the Image of the Malays, Filipinos and Javanese from the 16th to the 20th Century and Its Function in the Ideology of Colonial Capitalism. London: FrankCass, 1977. 
Al-Faruqi, Ismail Raji, "Islamizing the Social Sciences", in Ismail R. alFaruqi and Abdullah Omar Naseef (eds.), Social and Natural Sciences: The Islamic Perspective. Jeddah: King Abdullah University, 1981.

Berger, Peter L. and Luckman, Thomas. The Social Construction of Reality: A Treatise in the Sociology of Knowledge. New York: Doubleday and Company Inc, 1966.

Hanafi, Hassan. Oksidentalisme: Sikap Kita terhadap Tradisi Barat. trans. By Syafiq Hasyim and M. Najib Buchori. Jakarta: Paramadina, 1999.

Hussain, Asaf (et. al., eds.). Orientalism, Islam and Islamists. Vermont: Amana Books, 1984.

International Institute of Islamic Thought. Islamization of Knowledge: General Principles and Work Plan $2^{\text {nd }}$ Edition. Herndon, Virginia: IIIT, 1989.

Koch, M. Andrew. Knowledge and Social Construction. Lanham: Lexington Book, 2005.

Kuntowijoyo. Identitas Politik Umat Islam. Bandung: Mizan, 1997.

Kuntowijoyo. Muslim Tanpa Masjid. Bandung: Mizan, 2001.

Kuntowijoyo. Ilmu Sosial Profetik sebagai Gerakan Intelektual. Selangor: Akademi Kajian Ketamadunan, 2004.

Kuntowijoyo. Islam sebagai Ilmu: Epistemologi, Metodologi dan Etika. Jakarta: Teraju, 2005.

Kuntowijoyo. Maklumat Sastra Profetik. Yogyakarta: Grafindo Litera Media, 2006.

Kuntowijoyo. Paradigma Islam: Interpretasi Untuk Aksi. New edition. Bandung: Mizan, 2008. 
Laeyendecker, L. Tata Perubahan dan Ketimpangan: Suatu Pengantar Sejarah Sosiologi trans. by Sumekto. Jakarta: Gramedia, 1983.

Priyono, A.E., "Editor Introduction" in Kuntowijoyo, Paradigma Islam: Interpretasi Untuk Aksi. Bandung: Mizan, 2008.

Rahardjo, Dawam, "Ilmu Sejarah Profetik dan Analisis Transformasi Masyarakat", in Kuntowijoyo, Paradigma Islam: Interpretasi untuk Aksi. Bandung: Mizan, 2008.

Rahman, Fazlur. Islam dan Modernitas tentang Transformasi Intelektual. Bandung: Pustaka, 1995.

Sardar, Ziauddin. Orientalism, Buckingham: Open University Press. 1999. Shofan, Moh. Jalan Ketiga Pemikiran Islam. Yogyakarta: IRCISOD, 2004.

Woodward, Mark R., "Talking Across Paradigm: Indonesia, Islam and Orientalism", in Mark Woodward (ed.). Toward A New Paradigm: Recent Developments in Indonesian Islamic Thought. Arizona: Arizona State University, 1996. 